\begin{tabular}{cc|c}
\hline Tar. Bil. Der. & Tarım Bilimleri Dergisi & Journal of Agricultural Sciences \\
& $\begin{array}{c}\text { Dergi web sayfası: } \\
\text { www.agri.ankara.edu.tr/dergi }\end{array}$ & Journal homepage: \\
& www.agri.ankara.edu.tr/journal
\end{tabular}

\title{
Effects of Different Storage Conditions on the Nutritional Qualities of Barley and Maize
}

\author{
Havva Eylem POLAT ${ }^{\text {a }}$ \\ ${ }^{a}$ Ankara University, Faculty of Agriculture, Department of Farm Structures and Irrigation, 06110, Ankara, TURKEY
}

\section{ARTICLE INFO}

Research Article

DOI: 10.1501/Tarimbil 0000001326

Corresponding Author: Havva Eylem POLAT, E-posta: epolat@ankara.edu.tr, Tel: +90 (312) 5961206

Received: 10 November 2014, Received in Revised Form: 12 January 2015, Accepted: 15 January 2015

\begin{abstract}
The effects of different types of storage on nutritional quality values of barley and maize are examined. For this purpose, 3 different storage types, including horizontal-reinforced concrete storage, vertical-reinforced concrete silo and verticalsteel silo were taken into consideration. Nutritional quality values (dry matter, crude protein, crude fat, crude fiber, crude ash, and metabolizable energy) of samples were analyzed in the laboratory in four replicates. Total of 438 samples were collected from each of the stored product stacks during the storage for 12 months. Total average nutritional value losses have been found for barley were $1.74 \%$ in horizontal-reinforced concrete storage, $1.23 \%$ in reinforced concrete silo, $2.82 \%$ in vertical steel silo. These values have been found accordingly as $6.21 \%, 3.02 \%$, and $2.04 \%$ for maize stacks. As a result of this research, the vertical steel silo was determined to be more appropriate for maize storage while the horizontal-reinforced concrete storage structure and vertical reinforced concrete silo were suitable for barley storage.

Keywords: Barley; Grain storage; Horizontal grain storage; Maize; Reinforced concrete silo; Steel silo
\end{abstract}

\section{Farklı Depolama Koşullarının Arpa ve Mısırın Besin Kaliteleri Üzerindeki Etkileri}

\section{ESER BİLGISI}

Araştırma Makalesi

Sorumlu Yazar: Havva Eylem POLAT, E-posta: epolat@ankara.edu.tr, Tel: (+90) 3125961206

Geliş Tarihi: 10 Kasım 2014, Düzeltmelerin Gelişi: 12 Ocak 2015, Kabul: 15 Ocak 2015

\section{ÖZET}

$\mathrm{Bu}$ araştırmada, farklı depo tiplerinin arpa ve mısırın besin kaliteleri üzerindeki etkileri incelenmiştir. Bu amaçla, yatay betonarme depolama yapısı, düşey betonarme silo ve düşey çelik silo olmak üzere 3 farklı depolama tipi göz önüne alınmıştır. Alınan örneklerin yem besin değerleri (kuru madde, ham protein, ham yağ, ham selüloz, ham kül ve metabolize olabilen enerji) dört tekerrürlü olarak laboratuvar koşullarında analiz edilmiş̧ir. Depolanan her bir ürün yığınından 12 ay boyunca toplam 438 örnek alınmıştır. Toplam ortalama besin değeri kaybı, arpa için yatay betonarme depolama yapısında $\% 1.74$, betonarme çelik siloda \% 1.23 ve çelik siloda ise \% 2.82 bulunmuştur. Bu değerler mısır için ise sırasıyla \% 6.21, \% 3.02 ve \% 2.04 olarak hesaplanmıştır. Araştırmanın sonucunda, yatay betonarme depolama yapısı ve düşey betonarme çelik silo arpa depolaması için uygun bulunurken, düşey çelik silonun ise mısır depolaması için daha uygun olacağı belirlenmiştir. Anahtar Kelimeler: Arpa; Tahıl depolama; Yatay tahıl depolama yapısı; Mısır; Betonarme silo; Çelik silo 


\section{Introduction}

Containing the desired nutritional value by the feed depends on the sufficient quality of the feedstuffs composing the feed. The basic feedstuffs for feed are grains such as wheat, barley, maize, and oats. (Baran et al 2008). No matter how high the nutritional quality values of the feedstuffs of feed immediately after the harvest, they will lose these values in a short period of time due to improper storage (Didier et al 2003; Olgun 2013). Several diseases and digestive disorders emerge on farm animals which are fed with those feeds that lost its nutritional value. As a result, the yield decreases and the farmers fail to obtain the expected earnings (Olgun 2013). Approximately 13 million tons of grains are lost annually in the world due to improper storage. Also, 100 million tons of grains per year lose the value due to pests. According to researches, post-harvest storage losses may rise up to $10 \%$. Product loss due to storage outside silo is increased up to $15 \%$ (Dizlek et al 2008).

The respiratory and metabolic events in cereal grains continue during storage. Thus, the physical and biochemical changes occur on grains (Iconomou et al 2006). Some moisture change in grains is usual under normal storage conditions. However, if the humidity and temperature are not controlled in the environment, then the negative conditions such as mold, germination, decay, rancidity occur (Sharma et al 2007). This in turn may lead to huge losses in economic terms. The main objective of the storage is to protect the initial quality of the product as much as possible (Jones \& Shelton 1994). One of the most problematic issue throughout the post-harvest chain, because devastating pest can cause up to $30 \%$ dry matter losses in six months of storage (Golob \& Hanks 1990; Boxall 2002).

Volenik et al (2007), measured the temperature changes in grain bulks when ambient temperatures are $0{ }^{\circ} \mathrm{C}$ and $20{ }^{\circ} \mathrm{C}$ and relative humidity levels are $55 \%, 73 \%, 80 \%$ and $98 \%$. They concluded that the stack temperature increases as the temperature increases. Al-Yahya (2001), examined degradation in cereal grains at $4{ }^{\circ} \mathrm{C}, 15{ }^{\circ} \mathrm{C}, 25{ }^{\circ} \mathrm{C}$ and $40{ }^{\circ} \mathrm{C}$ degrees, under different relative humidity conditions and concluded that the degradation increases further at high temperature and humidity. When effective storage technology is not available, traditional storage technologies often unable to dry and store grain properly can even lead to increased losses during storage (Golob 2002).

Grains have high initial moisture content. High moisture damages grains by accelerating the mold growth. The moisture content is required to be reduced by drying process. Appropriate moisture level should be $13 \%$ for barley and maize. Ambient temperature and relative humidity inside the storage has a direct effect on temperatures in the product stack. The rise in the ambient temperature along with the humidity will cause the rise in temperature and humidity of product stacks. Increases in humidity at low temperatures can damage structural materials and has negative impact on the load-bearing, durability and insulating properties of the building. In both cases, there is a loss of nutritional value of cereal grains in a short period of time. Low humidity and temperature levels are always considered to be the most suitable storage conditions in terms of the protection of nutritional values of the grains. Average internal temperature of the storage should be $4{ }^{\circ} \mathrm{C}$ (Dizlek 2012). As the storage gets higher, ventilation in the storage should be increased at the appropriate levels or transferred to different storages with the appropriate temperature (Şişman \& Ergin 2011).

Storage of grains without losing the nutritional value is only possible with the provision of the required environmental conditions. The quality of construction of storage structure, used building and insulation materials, indoor ventilation, heating and cooling systems and the adequacy of storage volume are the most important factors that affect the success of the storage.

The most important quality criteria reflecting the nutritional value of grains used as feedstuffs for feed are dry matter, crude protein, crude fat, crude fiber, crude ash and metabolizable energy values. In this study, measurements of mentioned quality values of barley and maize grains have been made for 12 months in various storage structures. The obtained data are evaluated statistically. As a result, the most appropriate type of storage structure are tried to be determined for barley and maize. 


\section{Material and Methods}

In this study, changes in nutritional qualities of barley and maize have been studied for different storage types. In order to integrate the difference between storage types, it was paid attention to select the storage structures with the same external climatic conditions and very close to each other. To do this, storage facilities within the same campus of TMO (Turkish Grain Board) in Tekirdağ Office and Luleburgaz Agency in Marmara Region have been considered. Horizontalreinforced concrete storage, vertical - reinforced concrete silo and vertical-steel silo (steel bins) were taken into consideration for the measurement in this region. These storage types have shown in Figure 1.

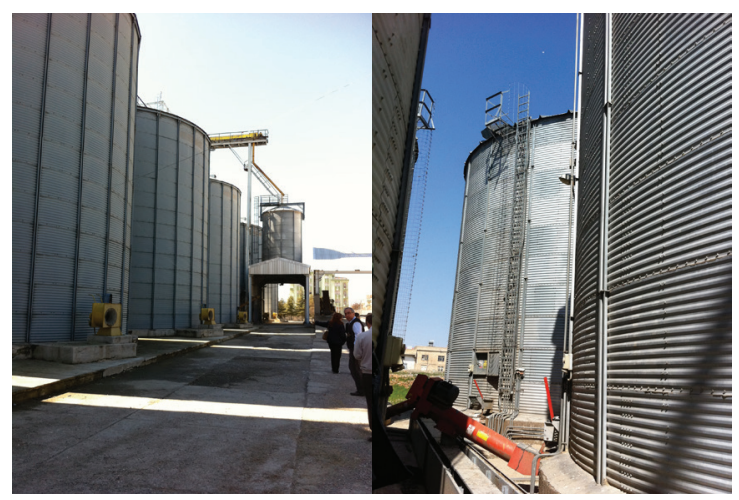

(a)

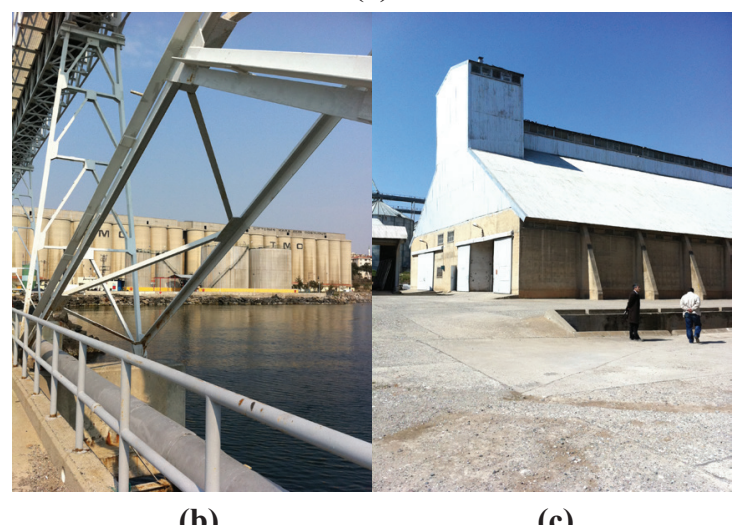

(b)

(c)

Figure 1-Three different storage types in research area (a-Vertical-steel silo, b-Vertical- reinforced concrete silo, c- Horizontal-reinforced concrete storage)

Şekil 1 - Araştırmanın yürütüldüğ̈̈ 3 farkl depolama tipi (a-Düssey çelik silo, b- Düşey betonarme silo, cYatay betonarme depo)
Table 1 shows some of the some technical characteristics of the different storage facilities where the research is carried out. Mechanical ventilation systems have been used in vertical steel silo and vertical reinforced concrete silo. Verticalreinforced concrete storage had three fans (each of fan has $5250 \mathrm{~m}^{3} \mathrm{~h}^{-1}$ ) and vertical-steel silo had four fans (each of fan has $4200 \mathrm{~m}^{3} \mathrm{~h}^{-1}$ ). The perforated floor was constructed in horizontal-reinforced concrete storage for air intake and the roof openings were built for air exhaust along the ridge pole of roof.

Samples were taken periodically (in every 15 days) from different depths of each batch of grain stacks which were filled into the storages at the same time. 73 samples were taken from each stack of the stored grains as one immediately before it was taken into the storage and the others during the storage (each sample weight of $1 \mathrm{~kg}$ ). A total of 438 samples were taken from all grain piles during the 12-month study period and their nutritional quality values (dry matter, crude protein, crude fat, crude fiber, crude ash and metabolizable energy) were examined. Each analysis was conducted in four replications.

Samples were taken in four repetitions from the center and sides corresponding to $25 \%$ and $75 \%$ of stack heights. Samples taken were prepared for analysis by $1 \mathrm{~mm}$ sieve. The guidelines and formulas specified in Kutlu (2008), Meyer et al (1983), Nehring (1960) and TSI standarts - 4966, 4664 EN ISO 5508, ISO 6541, ISO 20483, ISO 659 were taken into account for sample handling and analysis. The process sequence specified in AOAC (1990) was observed in the analysis to determine the values of the dry matter, crude protein, crude fat, and crude ash. The method specified in Crampton and Maynard (1983) was used to determine the crude fiber values. For the metabolizable energy calculations, equations described in Kutlu (2008), TSI (1991) and Ergün et al (2004) were used since the study is being conducted under the conditions of Turkey. The temperature and relative humidity also were all taken into account as a factor in the evaluation monitoring in the storage buildings. Temperature and relative humidity data of each 
stack is transmitted to the computer through using temperature and humidity probes at which 8 different points in stacks (two each from the bottom and the two side of the center level, one each from the center, the top, $25 \%$ and $75 \%$ levels of stacks).

The whole data transferred to the computer was evaluated by using the multivariate analysis of variance and regression analysis with the help of a packaged software. The evaluation was addressed separately for each grain and each storage type. Accordingly, the average, standard deviation, maximum and minimum measurement values were calculated and it was tried to determine whether effects of different storage types on the measured nutritional quality parameters are important. The results of the analysis were converted into tabular and graphical formats and the obtained information was summarized.

\section{Results and Discussion}

Changes in the storage and stack temperatures of barley and maize during 12 months of research are summarized in Figure 2. As shown in Figure 2 , it was understood that for barley storage, indoor temperatures of vertical steel silos were higher than the other type of silos and also the recommended values in literatures for safe storage (Proctor 1994; Hellevang 1995). Temperatures measured in maize storages were within acceptable limits except increasing levels measured sometimes in horizontal reinforced concrete storage. As a result of analysis of the samples taken from different storage structures for 12-month period, some important values for the dry matter, crude protein, crude fat, crude ash, crude fiber, and metabolizable energy (max, min, average, and standard deviation) are summarized in Table 2.

Other significant losses occurred in grains stored in horizontal reinforced concrete storage (Storage

Table 1- Technical features of different storage structures

Çizelge 1- Farklı depolama yapılarının teknik özellikleri

\begin{tabular}{|c|c|c|c|}
\hline Features & Storage 1 & Storage 2 & Storage 3 \\
\hline Storage Type & $\begin{array}{l}\text { Vertical-reinforced } \\
\text { concrete silo }\end{array}$ & $\begin{array}{l}\text { Vertical-steel silo } \\
\text { (Steel Bins) }\end{array}$ & $\begin{array}{l}\text { Horizontal-reinforced } \\
\text { concrete }\end{array}$ \\
\hline Structural material & Reinforced concrete & Steel & Reinforced concrete \\
\hline Storage capacity, metric ton & 1000 & 2500 & 1250 \\
\hline $\begin{array}{l}\text { Dimensions, } \mathrm{m} \\
\text { Width } \\
\text { Length } \\
\text { Height } \\
\text { Diameter }\end{array}$ & $\begin{array}{l}- \\
- \\
28.70 \\
8.30\end{array}$ & $\begin{array}{l}- \\
- \\
25.5 \\
15.6\end{array}$ & $\begin{array}{l}14.50 \\
45.00 \\
12.50 \\
-\end{array}$ \\
\hline $\begin{array}{l}\text { Ventilation } \\
\text { Heating System } \\
\text { Cooling System }\end{array}$ & $\begin{array}{l}\text { Mechanical (automated) } \\
\text { ventilation, fans } \\
\sqrt{ } \\
\sqrt{ }\end{array}$ & $\begin{array}{l}\text { Mechanical (automated), } \\
\text { ventilation, fans, } \\
\sqrt{ } \\
\sqrt{ }\end{array}$ & $\begin{array}{l}\text { Perforated floor, side } \\
\text { wall windows, roof ridge } \\
\text { ventilation } \\
\times \\
\times\end{array}$ \\
\hline $\begin{array}{l}\text { Temperature and Relative } \\
\text { Humidity Measurement } \\
\text { Filling-Loading } \\
\text { Unloading }\end{array}$ & $\begin{array}{l}\text { Temperature and Relative } \\
\text { Humidity probes in } \\
\text { different depth of piles } \\
\text { On the upper side via } \\
\text { mechanization } \\
\text { On the lower side via } \\
\text { conveyors }\end{array}$ & $\begin{array}{l}\text { Temperature and Relative } \\
\text { Humidity probes in } \\
\text { different depth of piles } \\
\text { On the building upper side } \\
\text { via mechanization } \\
\text { On the building lower side } \\
\text { via conveyors }\end{array}$ & $\begin{array}{l}\text { Temperature and Relative } \\
\text { Humidity probes in different } \\
\text { depth of piles } \\
\text { Trucks, front-end loaders } \\
\text { Trucks, front-end loaders }\end{array}$ \\
\hline
\end{tabular}

Tarım Bilimleri Dergisi - Journal of Agricultural Sciences 21 (2015) 246-255 
3). Maize has been the grain with the greatest loss among the products stored in Storage 3. While no significant losses found for barley in verticalreinforced concrete silos (Storage 1), maize losses were found to be statistically significant $(\mathrm{P}<0.01$, $\mathrm{P}<0.05)$. Barley losses in vertical-steel silos (Storage 2) were found to be statistically significant $(\mathrm{P}<0.01, \mathrm{P}<0.05)$.

The total loss of nutritional quality value in barley and maize were calculated according to the data obtained from Table 2. The total loss in barley was found to be $2.84 \%$ in horizontal reinforced concrete storage, $2.03 \%$, in vertical reinforced concrete silos, and $4.08 \%$ in vertical steel silos. These values were found as $6.92 \%, 4.56 \%$ and $2.14 \%$ in maize stacks. Standard deviation values of metabolizable energy parameter were calculated for barley are 20.14 in Storage 1, 19.47 in Storage 2, 10.43 in Storage 3 . These values were found as $28.25,24.10$, and 17.9 for maize, respectively. Results of laboratory analysis were statistically evaluated separately for each individual grain type, each grain pile and each storage type. The findings of the calculations are summarized below.

\subsection{Nutritional value losses of barley}

The losses that occur in barley grain stacks in four different storage types are summarized in the following Figure 3 as 2-month periods. The change observed in all nutritional quality values measured from the barley stacks in the vertical reinforced concrete silo was found to be
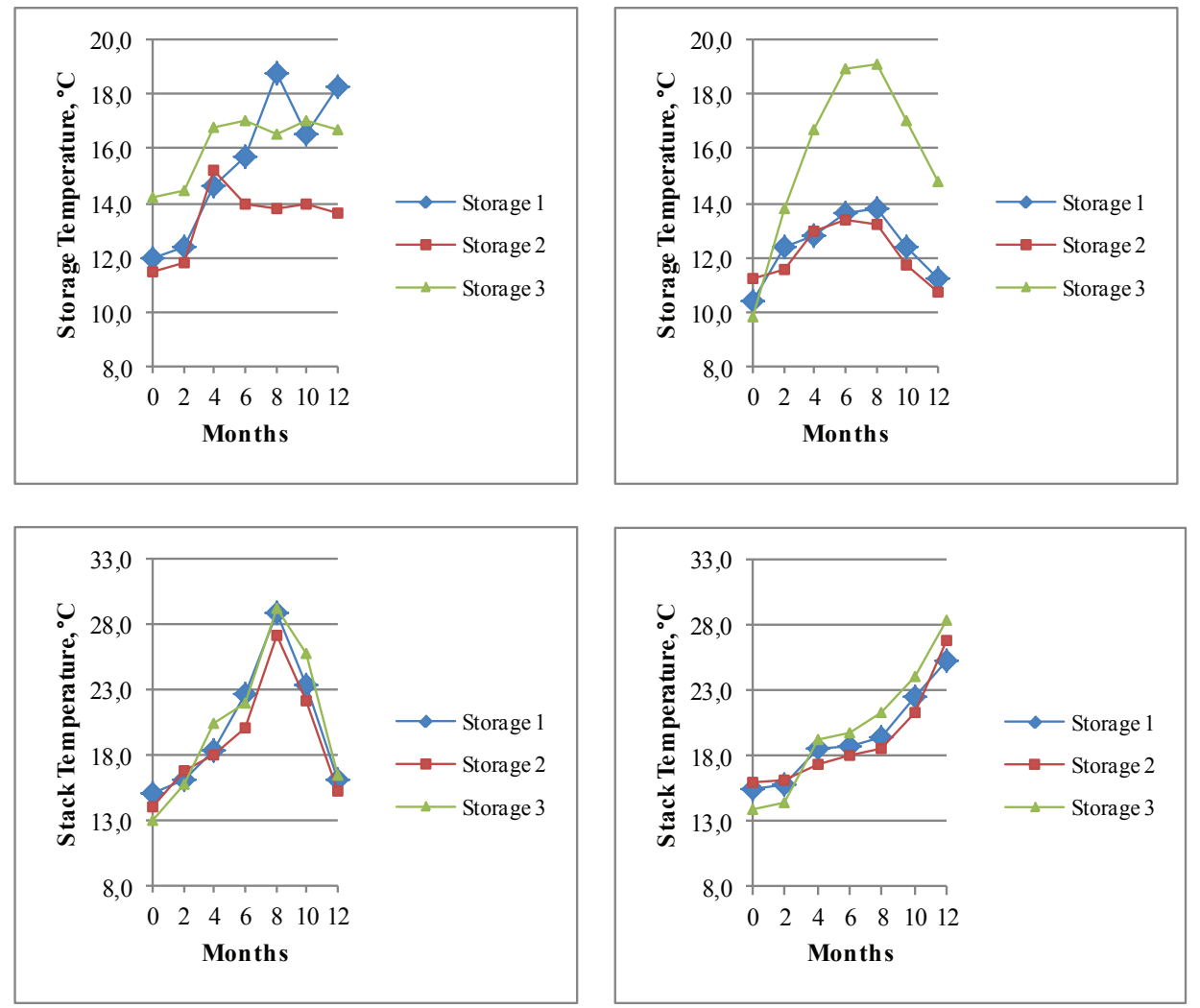

Figure 2- Changes in storage and stack temperatures of barley and maize

Şekil 2- Arpa ve misır depolarında ve yığınlarındaki sıcaklık değişimleri 
Table 2- Some important values of dry matter, crude protein, crude fat, crude ash, crude fiber (\%) and metabolizable energy (ME, kcal $\mathrm{kg}^{-1} \mathrm{OM}^{-1}$ ) contents of samples taken from grain stacks throughout the research

Çizelge 2-Araştırma boyunca tahıl yığınlarından alınan örneklerin kuru madde, ham protein, ham yağ, ham kül, ham selüloz ve metabolize enerji içeriklerinin bazı önemli değerleri

\begin{tabular}{|c|c|c|c|c|c|c|c|c|}
\hline \multirow{3}{*}{ Storage type } & \multicolumn{8}{|c|}{ Dry matter contents (\%) } \\
\hline & \multicolumn{4}{|c|}{ Barley } & \multicolumn{4}{|c|}{ Maize } \\
\hline & $\operatorname{Max}$. & Min. & $A v$. & S.D. & Max. & Min. & $A v$. & S.d. \\
\hline Storage 1 & 96.10 & 83.55 & 90.27 & 0.58 & 98.96 & 86.21 & 95.04 & 0.25 \\
\hline Storage 2 & 96.12 & 82.72 & 89.55 & 0.31 & 99.08 & 91.07 & 97.88 & 0.39 \\
\hline \multirow[t]{4}{*}{ Storage 3} & 96.10 & 83.44 & 90.31 & 0.75 & 98.82 & 76.28 & 87.63 & 0.35 \\
\hline & \multicolumn{8}{|c|}{ Crude protein (\%) } \\
\hline & \multicolumn{4}{|c|}{ Barley } & \multicolumn{4}{|c|}{ Maize } \\
\hline & Max. & Min. & $A v$. & S.D. & Max. & Min. & $A v$. & S.d. \\
\hline Storage 1 & 13.98 & 9.65 & 12.20 & 0.21 & 12.08 & 7.01 & 9.36 & 0.18 \\
\hline Storage 2 & 13.90 & 8.24 & 11.85 & 0.20 & 12.98 & 8.93 & 10.06 & 0.20 \\
\hline \multirow[t]{4}{*}{ Storage 3} & 13.97 & 9.85 & 12.29 & 0.21 & 12.04 & 5.02 & 8.94 & 0.54 \\
\hline & \multicolumn{8}{|c|}{ Crude fat (\%) } \\
\hline & \multicolumn{4}{|c|}{ Barley } & \multicolumn{4}{|c|}{ Maize } \\
\hline & Max. & Min. & $A v$ & S.D. & Max & Min. & $A v$. & S.d. \\
\hline Storage 1 & 4.02 & 2.88 & 3.39 & 0.20 & 6.90 & 2.30 & 4.52 & 0.21 \\
\hline Storage 2 & 4.01 & 2.03 & 3.10 & 0.11 & 6.98 & 3.85 & 5.77 & 0.10 \\
\hline \multirow[t]{4}{*}{ Storage 3} & 4.02 & 2.76 & 3.35 & 0.32 & 6.85 & 1.98 & 3.45 & 0.52 \\
\hline & \multicolumn{8}{|c|}{ Crude fiber (\%) } \\
\hline & \multicolumn{4}{|c|}{ Barley } & \multicolumn{4}{|c|}{ Maize } \\
\hline & Max. & Min. & $A v$. & S.D. & Max. & Min. & $A v$. & S.d. \\
\hline Storage 1 & 10.82 & 6.21 & 8.24 & 0.35 & 7.80 & 4.90 & 6.15 & 0.20 \\
\hline Storage 2 & 10.10 & 5.12 & 7.83 & 0.12 & 7.85 & 6.30 & 6.70 & 0.08 \\
\hline \multirow[t]{4}{*}{ Storage 3} & 10.47 & 6.41 & 8.59 & 0.33 & 7.76 & 2.90 & 5.49 & 0.58 \\
\hline & \multicolumn{8}{|c|}{ Crude ash (\%) } \\
\hline & \multicolumn{4}{|c|}{ Barley } & \multicolumn{4}{|c|}{ Maize } \\
\hline & Max. & Min. & $A v$. & S.D. & Max. & Min. & $A v$. & S.d. \\
\hline Storage 1 & 5.74 & 2.85 & 4.40 & 0.30 & 5.02 & 1.85 & 3.23 & 0.24 \\
\hline Storage 2 & 5.74 & 2.34 & 4.31 & 0.36 & 5.07 & 2.84 & 3.92 & 0.09 \\
\hline \multirow[t]{4}{*}{ Storage 3} & 5.76 & 3.01 & 4.52 & 0.54 & 4.80 & 1.65 & 2.85 & 0.21 \\
\hline & \multicolumn{8}{|c|}{ Metabolizable energy $\left(M E, \mathrm{kcal} \mathrm{kg}^{-1} \mathrm{OM}^{-1}\right)$} \\
\hline & \multicolumn{4}{|c|}{ Barley } & \multicolumn{4}{|c|}{ Maize } \\
\hline & Max. & Mir & & 1v. & $M a$ & $M$ & & $A v$. \\
\hline Storage 1 & 3152.50 & 274 & & 033.08 & 385 & & .05 & 3200.42 \\
\hline Storage 2 & 3160.25 & 291 & & 017.30 & 420 & & 12 & 3963.36 \\
\hline Storage 3 & 3148.27 & 288 & & 033.99 & 386 & & .01 & 3058.35 \\
\hline
\end{tabular}

statistically insignificant during the study period. While the changes in amount of dry matter, crude protein and metabolizable energy values in barley stored in horizontal concrete storage structure were found to be statistically significant $(\mathrm{P}<0.01)$, but changes in other parameters were found to be insignificant. It is considered that being the internal air conditioning process based on the natural conditions has been effective on the losses in the amount of dry matter, crude protein and metabolizable energy values in barley stored in horizontal concrete storage structure $(\mathrm{P}<0.01$, $\mathrm{P}<0.05)$.

At the end of the research period, the loss in the amount of stacks of barley was calculated as $1.54 \%$ 
in horizontal reinforced concrete storage, $1.20 \%$ in vertical reinforced concrete silos, and $2.80 \%$ in vertical steel silos.

The research area shows rainy and humid features in all seasons. Storage structures have also been near by the sea. Especially, high temperature with high humidity in the external environment causes to impair the quality of barley by rising the stack temperature and humidity in storages have inadequate insulation and ventilation systems. Therefore, the ventilation-heating-cooling systems must be use carefully and sufficient. The moisture
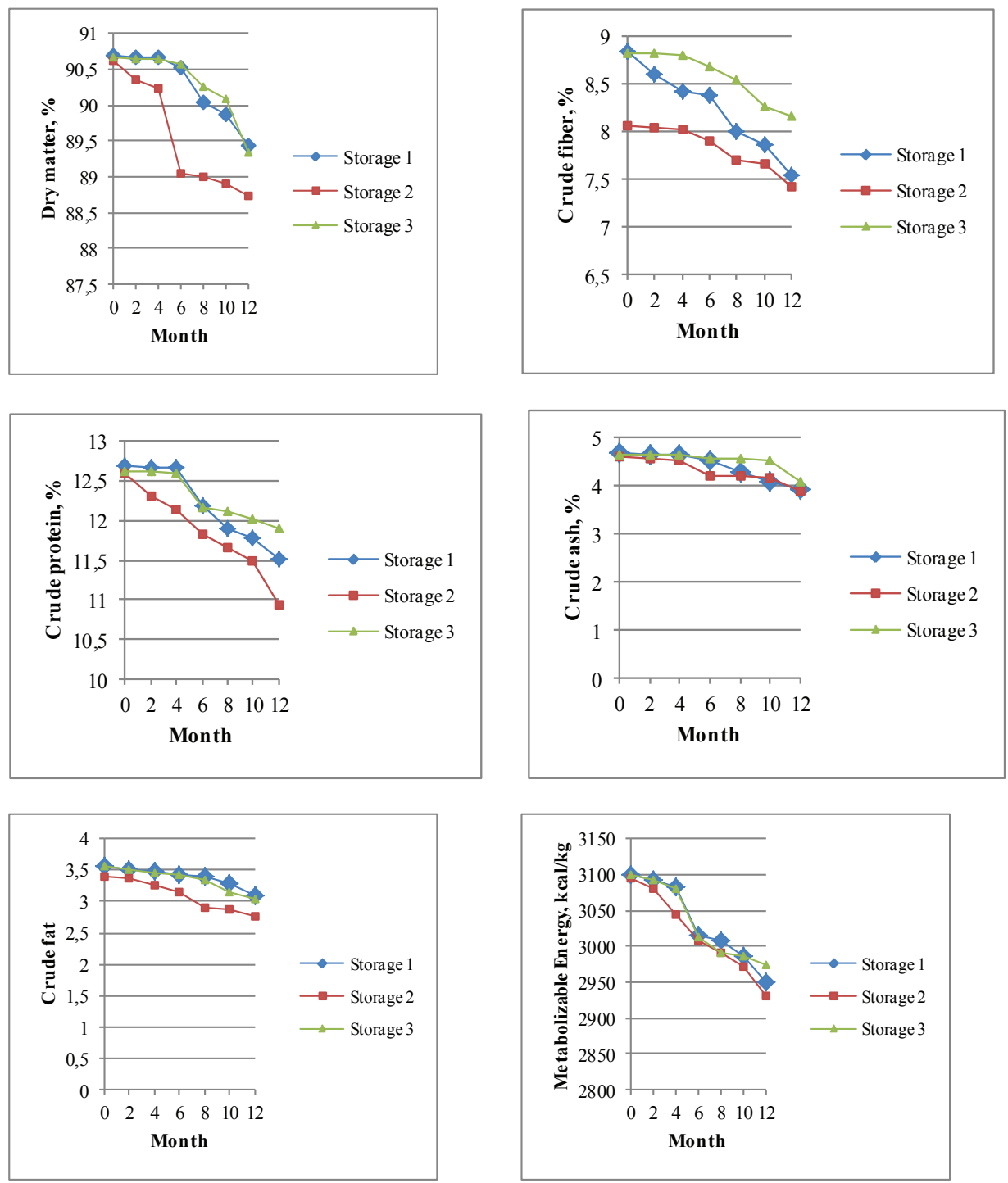

Figure 3- Changes in nutritional value parameters of barley

Şekil 3-Arpanın besin değeri parametrelerindeki değişimler 
content of fresh air taken into must be reduced in some time. The research carried out in the steel silo, it has not been controlled regularly moisture content of fresh air intake has been indicated by workers. Because of insufficient running or capacity of ventilation system caused to increase of losses in vertical steel silos. It can be say that another reason has been continuously loading and unloading process of stack for these losses. These were attributed to the increase in stack temperature and humidity resulting in damaging to product.

It is concluded that this type of storage structure would be appropriate for the storage of barley by ensuring the proper internal environmental conditions and the insulation. As a result of the evaluations, it can be said that vertical reinforced concrete and horizontal reinforced concrete storage structure are preferable for the storage of barley.

Temperature values measured in stacks of barley during the study period vary as per the storage types. Maximum temperatures were measured as $17^{\circ} \mathrm{C}$ in the horizontal reinforced concrete storage, $14{ }^{\circ} \mathrm{C}$ vertical reinforced concrete silos and $19{ }^{\circ} \mathrm{C}$ in vertical steel silos during the summer. Minimum temperatures were measured as $0{ }^{\circ} \mathrm{C}$ in the horizontal reinforced concrete storage, $1{ }^{\circ} \mathrm{C}$ vertical reinforced concrete silos and $-1{ }^{\circ} \mathrm{C}$ in vertical steel silos during the winter. During the research, the disruption of the air cooling system in concrete silos has led to the stack temperature rise at some times. It can be say that this is why higher temperature was measured. Insufficient ventilation and cooling systems caused to increase the indoor temperature and humidity levels.

\subsection{Nutritional value losses of maize}

The losses that occur in maize grain stacks in three different storage types are summarized in the following Figure 4 as 2-month periods. Examining the figure indicates that the vertical steel silo is more suitable for the storage of maize under all circumstances. As a result of the evaluation of the data obtained during the research period, the losses in the vertical steel silos were found insignificant.
Losses in the nutritional values in other storage types were found to be statistically significant $(\mathrm{P}<0.01, \mathrm{P}<0.05)$. At the end of the research period, the loss in the amount of stacks of maize was calculated as $5.30 \%$ in horizontal reinforced concrete storage, $3.06 \%$ in vertical reinforced concrete silos, and $1.72 \%$ in vertical steel silos.

Differences in storage types have impact on the temperature of the maize stacks. Maximum temperatures were measured as $20{ }^{\circ} \mathrm{C}$ in the horizontal reinforced concrete storage, $14^{\circ} \mathrm{C}$ vertical reinforced concrete silos and $14{ }^{\circ} \mathrm{C}$ in vertical steel silos during the summer. Minimum temperatures were measured as $4{ }^{\circ} \mathrm{C}$ in the horizontal reinforced concrete storage, $5{ }^{\circ} \mathrm{C}$ vertical reinforced concrete silos and $6^{\circ} \mathrm{C}$ in vertical steel silos during the winter.

\section{Conclusions}

According to the data obtained, it is concluded that the horizontal reinforced concrete storage structure and vertical reinforced concrete silos for barley and the vertical steel silos for maize are the most economical and appropriate storage types in terms of the protection of the nutrient quality values and reduction of the losses in quantity. Horizontal reinforced concrete storage seems to be a suitable storage structure on condition the use of high quality building material with right insulation and air-conditioning. However, large internal volume of the building has the effect of increasing the costs required for air-conditioning. This storage type may not be economical for farmers nowadays.

Vertical-reinforced concrete silos are the most appropriate storage type especially for the storage of barley, since it allows automation systems to be used easily. Vertical-steel silo is the most commonly used type of storage today. The biggest advantage is the ease of construction and installation. However, it is very important to provide the waterproofing well between the bottom-floor and steel covering material mounted on top, especially in flat bottom vertical-steel silos. In addition, because of the thermal conductivity characteristics of steel material, the internal air- 

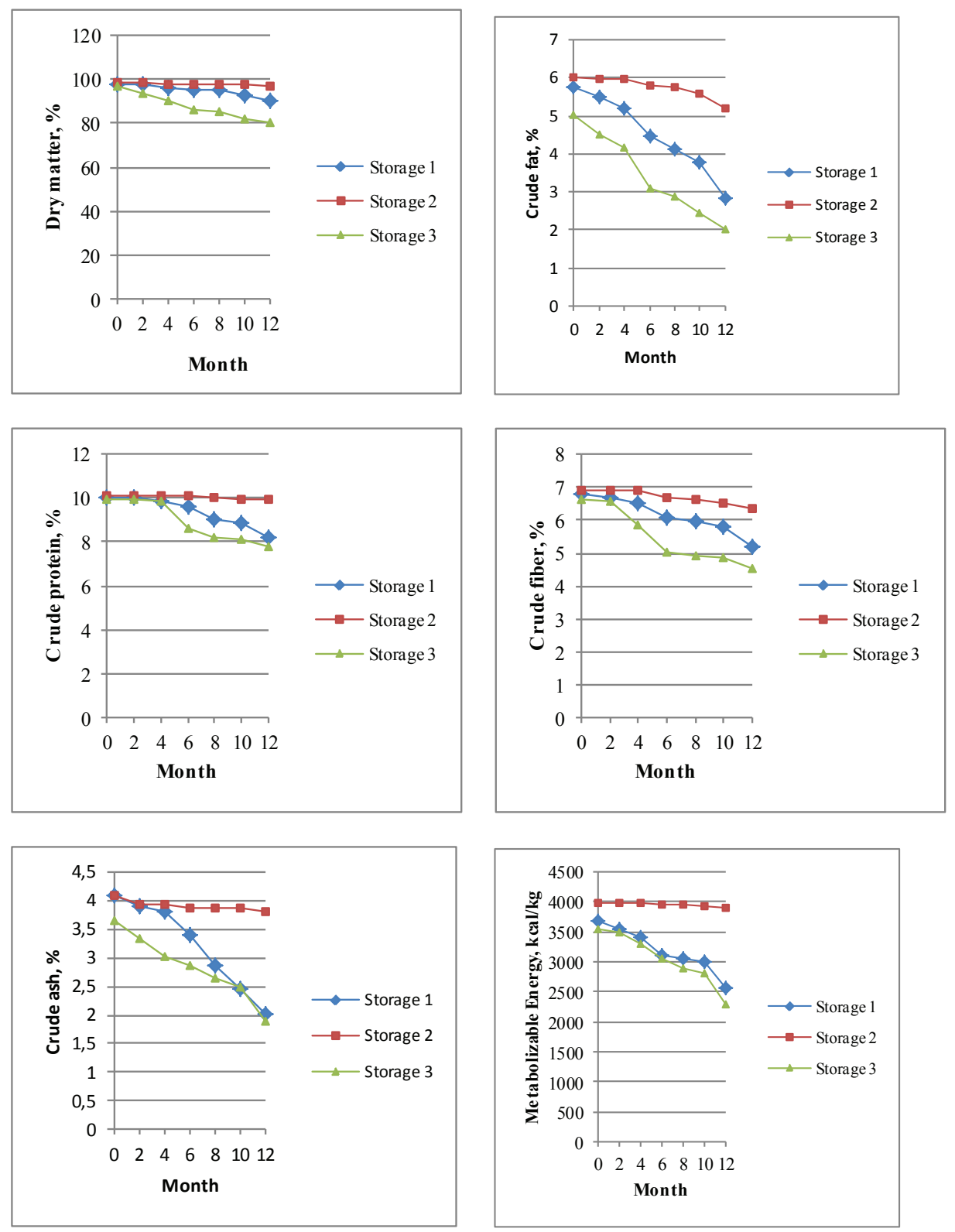

Figure 4- Changes in nutritional value parameters of maize

Şekil 4-Misırın besin değeri parametrelerindeki değişimler

conditioning must be automated and kept under constant control. It can be used for the safe storage of maize. Research result demonstrates that the internal climatic conditions should be kept under constant control to provide the requirements of the stored grains, whichever storage type is used. 


\section{References}

Al-Yahya S A (2001). Effect of storage conditions on germination in wheat. Journal of Agronomy \& Crop Science 186: 273-279

AOAC (1990). 992.23 - Cereal grains and oilseeds. Official methods of analysis. 15th edition, Assoc. of Analytical Chemists, Arlington, VA

Baran M S, Demirel R, Şentürk D, Şahin T \& Yeşilbağ D (2008). Determination of the feeding values of feedstuffs and mixed feeds used in the Southeastern Anatolia Region of Turkey. Turkish Journal of Veterinary Animal Sciences 32(6): 449-455

Boxall R A (2002). Damage and loss caused by the larger grain borer prostephanus truncates. Integrated Pest Management Reviews 7: 105-121

Crampton E \& Maynard L (1983). The relation of cellulose and lignin content to nutritive value of animal feeds. Journal of Nutrition 15: 383-395

Didier K Jacob R G, Corinne A \& Abdoulaye T (2013). Effects of storage losses and grain management practices on storage: Evidence from maize production in Benin. Agricultural \& Applied Economics Association's 2013 AAEA \& CAES Joint Annual Meeting, Washington, DC, August 4-6

Dizlek H (2012). Depolama sirasında tahıllarda meydana gelen fiziksel ve kimyasal değişiklikler. Gıda ve Yem Bilimi-Teknolojisi Dergisi 12: 49-57

Dizlek H, Gül H \& Kılıçdağı R (2008). Grain storage problems and suggestions. 10. Food Congress Abstracts Book, 21-23 May, Erzurum, pp. 391-394

EN ISO 5508 (2013). Animal and vegetable fats and oils - Analysis by gas chromatography of methyl esters of fatty acids

Ergün A, Tuncer Ş D, Çolpan İ, Yalçın S, Yıldız G, Küçükersan K M, Küçükersan S \& Şehu A (2004). Feeds, feed hygen and technology. Ankara University Faculty of Veterinary Course Book

Golob P \& Hanks C (1990). Protection of farm stored maize against infestation by Prostephanus truncatus (Horn) and Sitiphilus species in Tanzania. Journal of Stored Products Research 2: 187-198

Golob P (2002). Chemical, physical and cultural control of prostephanus truncates. Integrated Pest Management Reviews 7: 245-277

Hall C W (1980). Drying and storage of agricultural crops. The AVI Publishing Company Inc., USA

Hellevang K J (1995). Grain moisture content effects and management, NDSU Extension Service, AE-905, pp. 9

Iconomou D, Athanasopoulos P, Arapoglou D, Varzakas $\mathrm{T} \&$ Christopoulou N (2006). Cereal quality characteristics as affected by controlled atmospheric storage conditions. American Journal Food Technology 1: 149-157

ISO 20483 (2013) Cereals and pulses - Determination of the nitrogen content and calculation of the crude protein content - Kjeldahl method

ISO 6541 (2013). Agricultural food products Determination of crude fibre content - Modified Scharrer method

ISO 659 (2009). Determination of oil content (reference method)

Jones D \& Shelton P (1994). Management to maintain stored grain quality. NSU Coop.Ex.Service, G-941199-A, USA

Kutlu H R (2008). Feed Handling and Analysis Methods. Çukurova University, Faculty of Agriculture, Animal Science Department, Course Notes, Adana

Meyer H, Bronsch K \& Leibetseder J (1983). Suplemente $\mathrm{zu}$ volesungen und ubungen in der tierernaehrung. Verlag Sprungman, Hannover

Nehring K (1960). Agriculture chemische untersuchungs methoden für dünge-und futtermittel böden und mile, Verlagpaul Parey, Hamburg and Berlin

Olgun M (2013). Agricultural structures. Ankara University Faculty of Agriculture Publishing No:1577, Ankara

Proctor D L (1994). Grain storage techniques: Evolution and trends in developing countries, FAO

Sharma S, Gambhir S \& Munshi S K (2007). Changes in lipid and carbohydrate composition of germinating soybean seeds under different storage conditions. Asian Journal of Plant Science 6: 502-507

Sisman C B \& Ergin S (2011). The effects of different storage buildings on wheat quality. Journal of Applied Sciences 11(14): 2613-2619

TSI (1991). Turkish Standard Institute, TS 9610- Animal feeds-metabolic energy determination (chemical method). Ankara

TSI (2009). TS 4664 - Animal and vegetable fats and oils - Analysis by gas chromatography of methyl esters of fatty acids

TSI (2009). TS 4966 - Agricultural food products Determination of crude fibre content - Modified Scharrer method

Volenik M, Rozman V, Kalinovic I, Liska A, Kis D \& Simic B (2007). Influence of relative humidity and temperature on the changes in grain moisture in stored soybean and maize. Agriculturae Conspectus Scientificus 72(3):215-219 